\title{
Panel of Genetic Variations as a Potential Non-invasive Biomarker for Early Diagnosis of Alzheimer's Disease
}

\author{
Suk Ling Ma,2, Linda Chiu Wa Lam ${ }^{2}$ \\ ${ }^{1}$ Department of Medicine, Beth Israel Deaconess Medical Center and Harvard Medical School, Boston, MA, USA, ²Department of Psychiatry, \\ Faculty of Medicine, The Chinese University of Hong Kong, Hong Kong
}

\begin{abstract}
Alzheimer's disease (AD) is the most prevalent form of dementia. Biomarkers such as levels of amyloid beta (A $\beta$ ) in cerebrospinal fluid and ApoE genotyping were suggested for the diagnosis of $A D$, however, the result is either non-conclusive or with invasive procedure. Genome-wide association studies (GWASs) for AD suggested single nucleotide polymorphisms (SNPS) in many genes are associated with the risk of $A D$, but each only contributed with small effect to the disease. By incorporating a panel of established genetic susceptibility factors, the risk of an individual in getting AD could be better estimated. Further research will be required to reveal if adding to the current well-developed clinical diagnosis protocol, the accuracy and specificity of diagnosis of $A D$ would be greatly improved and if this might also be beneficial in identifying pre-symptomatic AD patients for early diagnosis and intervention of the disease.
\end{abstract}

KEY WORDS: Alzheimer disease; Genetics; Biomarkers; Diagnosis.

\section{INTRODUCTION}

Alzheimer's disease (AD) is the most prevalent form of age-related dementia and it is currently affecting more than 30 million people worldwide and the number of people with AD will have doubled to 46 million by $2020 .{ }^{1)}$ It has been estimated that delaying the mean age of onset of $\mathrm{AD}$ by about 5 years would reduce the number of individuals with this disease by $50 \%$ by 2050 . Mild cognitive impairment $(\mathrm{MCI})$ is a clinical diagnosis for individuals who have cognitive deficits but do not fulfill the diagnosis of dementia that may represent the early stage of $\mathrm{AD}^{2-4)}$ Studies showed that the annual conversion rate for individuals with $\mathrm{MCI}$ to $\mathrm{AD}$ is $10-12 \%$, compared to the conversion rate of $1-2 \%$ in the normal elderly population. ${ }^{3)}$ Therefore, early detection of $\mathrm{AD}$ and accurate prediction of progression from $\mathrm{MCI}$ to $\mathrm{AD}$ are the important areas of research in $\mathrm{AD}$.

Over the past decades, basic and clinical research studies provided a lot of knowledge on the molecular mecha-

\footnotetext{
Received: March 16, 2011/ Revised: May 6, 2011

Accepted: May 23, 2011

Address for correspondence: Suk Ling Ma, MD, PhD Department of Psychiatry, Faculty of Medicine, The Chinese University of Hong Kong, Hong Kong

Tel: +852-2607-6032, Fax: +852-2667-1255

E-mail:suklingma@cuhk.edu.hk
}

nism and the clinical progression of the disease. AD is characterized by the deposition of amyloid plaques composed of amyloid beta-peptides (A $\beta$ ) derived from amyloid precursor protein (APP) and the formation of neurofibrillary tangles composed of hyperphosphorylated tau. ${ }^{5}$ $\mathrm{AD}$ is mainly classified into two groups: (1) early-onset $\mathrm{AD}$, which accounts for 1-6\% of all cases and has its onset before the age of 65 years, and (2) late-onset $\mathrm{AD}$, which is responsible for the vast majority (94-99\%) of cases and symptoms appear after 65 years old. Several causative mutations on APP, presenilin 1 (PSEN1) and presenilin 2 (PSEN2) have been identified in familial type AD. ${ }^{6}$ On the other hand, late-onset $\mathrm{AD}$ is a complex neurodegenerative disease and it is caused by genetic and environmental risk factors.

\section{DIAGNOSIS OF AD}

The diagnosis of $\mathrm{AD}$ is based on clinical examination using criteria of the National Institute of Neurological and Communicative Disorders and Strokes and the Alzheimer's Disease and Related Disorders Association Work Group (NINCDS-ADRDA). ${ }^{7)}$ The diagnostic criteria are well-established and have high reliability and consistency. ${ }^{8,9)}$ Definitive diagnosis of AD can only be achieved by postmortem examination based on the histopathologic 
confirmation. Although the diagnostic criteria have good reliability and validity, it is not designed to identify patients with very mild symptoms or to assess the probability of conversion from $\mathrm{MCI}$ to $\mathrm{AD}$.

\section{BIOMARKERS}

In the past decades, a large number of independent studies were carried out to evaluate the use of biomarkers in facilitating reliable diagnosis of $\mathrm{AD}$, even in the preclinical stage. Based on the pathological importance of amyloid plaques and neurofibrillary tangles on $\mathrm{AD}$, the levels of $\mathrm{A}$ $\beta 40, \mathrm{~A} \beta 42$, total tau and phosphorylated tau (p-tau) in cerebrospinal fluid (CSF) have emerged as the major biomarkers of interest. ${ }^{10-14)} \mathrm{A} \beta 40$ and $\mathrm{A} \beta 42$ are produced from APP cleavage pathway. Based on the observation that increased production of $\mathrm{A} \beta 42$ in missense mutations in the APP, PS1 and PS2 genes which cause familial AD, suggesting $A \quad \beta 42$ plays a central role in the pathogenesis of AD. ${ }^{15)}$ Studies suggested that the concentration of $\mathrm{A} \beta$ 42 in CSF is significantly lower in AD patients when compared to the age-matched normal controls. ${ }^{16)}$ On the other hand, total tau in CSF reflects the formation of neurofibrillary tangles in AD. Elevated level of total tau in AD patients have been reported and reviewed in a meta-analysis study. ${ }^{14,17-19)}$ However, elevated level of total tau in CSF is not a specific marker for AD as it is also observed in fronto-temporal dementia (FTD), ${ }^{10)}$ vascular dementia $^{20)}$ and acute ischemic stroke. On the other hand, $\mathrm{p}$-tau is a more specific biomarker for $\mathrm{AD}$ as elevated level of p-tau is only detected in AD but not other neurological diseases such as Lewy body dementia and FTD. ${ }^{21,22)}$

The National Institute on Aging Working Group outlined several criteria for an ideal diagnostic biomarker including fundamental relatedness to the disease, validation, high sensitivity and specificity. Also, the biomarkers should be noninvasive, inexpensive and readily available. ${ }^{23)}$ However, sampling CSF requires the lumbar puncture which is an invasive procedure and the cost for CSF testing is expensive.

\section{IMAGING}

Recent advances in functional and molecular neuroimaging provided insights into brain structure and physiology. Imaging techniques such as magnetic resonance imaging (MRI), functional MRI (fMRI), magnetic resonance spectroscopy (MRS) and positron emission tomography (PET) provided information on the regional changes of the brain in $\mathrm{AD}$ patients when compared to normal age-matched controls. MRI can be used to measure the degree of atrophy and it provided information on the disease state and progression. MRI-based atrophic changes are well matched with the pathological changes of tau deposition. ${ }^{24-27)}$

Microstructural changes such as loss in dendrites, myelin and axon in $\mathrm{AD}$ can be detected by MRS. ${ }^{28)}$ Combining the use of radiological-contrast compounds and imaging techniques, some promising diagnostic tool has been studied. One of the widely studied amyloid-binding compounds is ${ }^{11} \mathrm{C}$-PIB (PIB, Pittsburgh compound B). The uptake of PIB was measured by PET and AD patients showed specific retention of PIB in regions of the brain which is corresponded to the location of amyloid deposition. ${ }^{29)}$ However, there was also studies reporting elderly subjects without MCI showing increased uptake of ${ }^{11} \mathrm{C}$-PIB ${ }^{30,31)}$ but it is uncertain whether this imaging marker has prognostic implications on $\mathrm{AD}$.

\section{GENETIC STUDIES IN AD}

ApoE is a widely accepted genetic risk factor for late-onset sporadic AD. Studies showed that $\varepsilon 4$ allele increased $\mathrm{AD}$ risk in a dose-dependent manner while $\varepsilon 2$ allele has a protective effect on $\mathrm{AD} .^{32-34)}$ However, bearing $\varepsilon 4$ allele is neither sufficient nor necessary for the development of AD. Many linkage studies were performed to identify the chromosome/loci associated with the risk of $\mathrm{AD}$ and identified the ApoE region on chromosome 19 as the risk locus for $\mathrm{AD}{ }^{35-37)}$ This provided further evidence for the association of ApoE and the risk of AD. On the other hand, several linkage studies identified other regions on chromosome $6,^{35,36,38,39)} 9,^{35,36)} 10^{35,39,40)}$ and $12^{41,42)}$ other than chromosome 19 to be associated with the risk of $\mathrm{AD}$, suggesting genes other than ApoE are involved in the genetics of this complex disease. These linkage studies not only providing further evidence of the involvement of multiple chromosomal regions to the association of the risk of $\mathrm{AD}$, it provided the bases for the individual candidate gene studies. One of the example is tumour necrosis factor- $\alpha$ (TNF $\alpha$ ), which is located on chromosome $6 \mathrm{p} 21$ and it was identified by several linkage studies to be significantly associated with the risk of AD..$^{36,38,39,41)}$ Genetic association studies also showed significant association of TNF $\alpha$ polymorphism and the risk of AD. ${ }^{43-47)}$

With the advance of genotyping technology and the launching of International HapMap project, ${ }^{48)}$ many large scale genome-wide association studies (GWASs) were 
Table 1. Summary of results of genome-ide association study in $A D$

\begin{tabular}{|c|c|c|c|c|c|}
\hline Studies & $A D$ & Normal & Gene & $p$ value & Odds ratio \\
\hline Grupe et $a . .^{190)}$ & 1808 & 2062 & $\begin{array}{l}\text { TOMM40, APoE, GALP, TNK1, APOC2, } \\
\text { PCK 1, LMNA, PGBD1, THEMS, MYH13, } \\
\text { CTSS, UBD BCR, AGC1 TRAK2, EBF3 }\end{array}$ & 0.001 to $1.0 \times 10^{-8}$ & 1.07 to 2.73 \\
\hline $\mathrm{Li}$ et $a l^{128)}$ & 753 & 736 & $\begin{array}{l}\text { GOL, UBD, BCK, AGC I, IRAKL, EBFS } \\
\text { GOLPH2 }\end{array}$ & $9.82 \times 10^{-3}$ & 0.51 \\
\hline Abraham et al. ${ }^{191)}$ & 1082 & 1239 & LRAT & $3.4 \times 10^{-6}$ to $6.1 \times 10^{-7}$ & 1.2 to 1.3 \\
\hline Bertram et al. ${ }^{192)}$ & 1376 & & chr 14q31, chr19q13 & $6.0 \times 10^{-6}$ to $2.0 \times 10^{-6}$ & 1.1 to 1.4 \\
\hline Beecham et al. ${ }^{193)}$ & 730 & 718 & chr 12 q 13 & $3.4 \times 10^{-7}$ & - \\
\hline Feulner et $a l^{194)}$ & 491 & 479 & $\begin{array}{l}\text { MAPT, SORL1, CHRNB2, CH25H, GAB2, } \\
\text { PGBD1, PCK1, LMNA }\end{array}$ & 0.05 to $6.8 \times 10^{-3}$ & - \\
\hline Harold et $a l^{50)}$ & $\begin{array}{l}4957 \text { (Stage 1) } \\
2023 \text { (Stage 2) }\end{array}$ & $\begin{array}{l}9682 \text { (Stage 1) } \\
2340 \text { (Stage 2) }\end{array}$ & CLU, PICALM & $1.3 \times 10^{-9}$ to $8.5 \times 10^{-10}$ & 0.86 \\
\hline Lambert et $a .^{51)}$ & 2032 (Stage 1) & 5328 (Stage 1) & CLU, CR1 & $3.7 \times 10^{-9}$ to $7.5 \times 10^{-9}$ & 0.86 to 1.21 \\
\hline Seshadri et $a l^{87)}$ & $\begin{array}{l}3006 \text { (Stage 1) } \\
2032 \text { (Stage 2) }\end{array}$ & $\begin{array}{r}14642 \text { (Stage 1) } \\
5328 \text { (Stage 2) }\end{array}$ & $\begin{array}{l}\text { BIN1, EXOC3L2/BLOC1S3/ MARK4, CLU, } \\
\text { PICALM }\end{array}$ & 0.007 to 0.03 & 0.82 to 1.26 \\
\hline
\end{tabular}

AD, Alzheimer's disease; CLU, clusterin.

performed to investigate the genes associated with the risk of AD. GWASs simultaneously genotyped a large number of genetic markers in a unbiased setting as the single nucleotide polymorphisms (SNPs) to be genotyped were chosen to cover the common variations in human genome. ${ }^{49)}$ Until now, more than 10 AD GWASs were performed and a number of candidate genes for the risk of $A D$ were identified. The results from the GWASs of AD were summarized in Table 1. Individual genetic association studies were also performed to follow-up and validate the findings from GWASs in different populations. Interestingly, these GWASs identified different candidate genes for the risk of $\mathrm{AD}$ but they consistently resulted in significant association of Apolipoprotein E (ApoE) and the risk of AD. Recent GWASs identified three genes including CLU, CR1 and phosphatidylinositol binding clathrin assembly protein (PICALM) as the susceptibility genes for $\mathrm{AD}^{50,51)}$

Since the identification of the association of ApoE and the risk of $\mathrm{AD}$, it remains to be the most widely studied gene in AD. AlzGene website (http://www.alzgene.org) ${ }^{33)}$ is a database with continuously updated list of genes associating with $\mathrm{AD}$. The database provided the results of allele-based meta-analyses for all polymorphisms with sufficient genotype data and ranked the genes based on the genetic variant with the strongest association (HuGENet/Venice criteria, $p$-value and effect size) to AD. In the database, there is a "Top Results" list showing the "most promising" AD candidate genes and it could help in choosing the genes in high priority for future studies. However, there is unavoidable limitation of the database such as possibility in overlooking the studies, allele analysis instead of genotype analysis (less powerful in revealing the underlying mode of inheritance), lack of haplotype data or consideration of co-variates such as age or gender.
According to the statistics of AlzGene as of October 2010, the top ten genes showed the strongest association in $\mathrm{AD}$ are ApoE, CLU, PICALM, EXOC3L2, BIN1, CR1, SORL1, GWA_14q32.13, TNK1 and IL8.

\section{GENETIC VARIATIONS AS MARKERS FOR ALZHEIMER'S DISEASE}

Results from GWASs and linkage studies in AD identified several genes/SNPs conferring to the risk of AD. In addition, twin studies suggested that the additive genetic effects contributed $37 \%$ to $75 \%$ to the variance in age-at-onset of $\mathrm{AD}^{52)}$ On the other hand, it is uncommon to have large implication of a single gene in common diseases such as AD. For most genes or SNPs, they only conferred a modest risk to the disease. It is unlikely that any single genetic polymorphism would be sufficient to be a reliable marker as diagnostic and prognostic tool, but a panel of genetic variation markers might serve this purpose. Recently, a study reporting 95 loci associated with lipid traits was based on analyzing the result of 59 GWAS, ${ }^{53)}$ which made the idea of developing a panel of genetic marker as diagnostic and prognostic tool for $\mathrm{AD}$ promising. In this review, the relatedness and usefulness of using genetic variations in AD susceptibility genes as diagnostic tool and markers will be discussed.

\section{ApoE}

ApoE gene is mapped to chromosome $19 \mathrm{q} 13.2$ and it is expressed in liver, brain and cells such as macrophages and monocytes. ${ }^{54)}$ There are three isoforms of ApoE coded for by $\varepsilon 2, \varepsilon 3$ and $\varepsilon 4$ alleles. A dose-dependent effect of ApoE $\varepsilon 4$ and the risk of $\mathrm{AD}$ was reported in late-onset $\mathrm{AD}^{34)}$ and the finding was replicated by differ- 
ent groups in different populations. ${ }^{32,55-58)}$ It is by far the most widely studied and replicated genetic polymorphism conferring to the risk of $\mathrm{AD}$, up to $20-50 \%{ }^{59)}$ Bearing $\varepsilon 4$ allele increased the risk for $\mathrm{AD}$ from $20 \%$ to $90 \%$ and decreased the age-at-onset from 84 to 68 years with an increased dose of ApoE $\varepsilon 4$ alleles. ${ }^{34,60)}$ Moreover, biochemical data showed ApoE was associated with amyloid in senile plaques ${ }^{61)}$ and neurofibrillary tangles. ${ }^{62,63)}$ Different isoforms of ApoE bind $\mathrm{A} \beta$ in different rate and $\varepsilon 4$ binds to $\mathrm{A} \beta$ at a faster rate when compared to $\varepsilon 3$. $^{64)}$ On the other hand, both ApoE $\varepsilon 2$ and $\varepsilon 3$ bind to tau protein but not $\varepsilon 4$, suggesting the interaction between ApoE and tau may serve as a protective function and this might explain the biological significance of $\varepsilon 4$ as a risk factor for AD. Until now, almost all GWASs in AD identified ApoE as a susceptibility locus and the association of ApoE $\varepsilon 4$ and the risk of AD was replicated and confirmed in large number of studies in different populations.

There is a dose-dependent effect of ApoE and the risk of AD where $55 \%$ of ApoE $\varepsilon 4 / \varepsilon 4$ group developed AD, compared with $27 \%$ of ApoE $\varepsilon 3 / \varepsilon 4$ and $9 \%$ of ApoE $\varepsilon 3 /$ $\varepsilon 3$ groups. ${ }^{65)}$ The frequency of $\varepsilon 4$ is less than $20 \%$ compared to $\varepsilon 3$, with a frequency of over $65 \%$, ${ }^{66)}$ therefore it is unlikely the genotype of $\mathrm{ApoE}$ alone is sensitive enough to diagnose AD. It is clear that bearing ApoE $\varepsilon 4$ allele increased the risk of AD but not essential for the development of AD. Several studies assessed the specificity and sensitivity of ApoE genotyping in the diagnosis of AD. The sensitivity of ApoE genotyping for the diagnosis of $\mathrm{AD}$ varied and it ranged from $19 \%$ to $75 \% .{ }^{67-70)}$ Mayeux et $a l .{ }^{68)}$ assessed the specificity and sensitivity of ApoE genotyping, clinical diagnosis and the combination of both techniques in more than $2000 \mathrm{AD}$ patients. They reported the specificity of clinical diagnosis and ApoE genotyping alone were $55 \%$ and $68 \%$ respectively, although the sensitivity of clinical diagnosis was much higher than ApoE genotyping, with $93 \%$ versus $65 \%$. They further analysed the specificity of combining both techniques and it increased to $84 \%$, suggesting the combination of clinical diagnosis and ApoE genotyping would greatly reduce the false positive rate. Overall, the specificity of clinical diagnosis and ApoE genotyping were 50-55\% and 68-71\% respectively ${ }^{68,71)}$ but the sensitivity of ApoE genotyping was much lower than clinical diagnosis, with only 59-65\% compared to clinical diagnosis yielding up to $93 \%$. The specificity of diagnosis with both clinical diagnosis and ApoE genotyping was greatly increased to $84 \%$, which was higher than either method alone. A study examining the predictive value of ApoE genotyping in 69 patients who had been clinically diagnosed with probable AD and $85 \%$ of them were confirmed to have AD at autopsy. No non-AD demented patients were found to carry ApoE $\varepsilon 4$ allele and $75 \%$ autopsy-confirmed $\mathrm{AD}$ patients carried at least one $\varepsilon 4$ allele, which gave a $100 \%$ specificity of ApoE genotyping in predicting AD. ${ }^{67)}$ However, there was also study showing that $50 \%$ of individuals carrying at least one $\varepsilon 4$ allele did not develop $\mathrm{AD}$ in their lifetime. ${ }^{72)}$ Therefore, ApoE genotyping alone does not have sufficient specificity and sensitivity for the diagnosis of $\mathrm{AD}$ but it might be used as a adjutant test to improve the accuracy of clinical diagnosis of $\mathrm{AD}$.

\section{CLU}

Clusterin (CLU), also named as apolipoprotein $\mathrm{J}$, is mapped on chromosome 8. Like ApoE, it is a lipoprotein that widely expressed in most tissues, with higher levels in brain, liver, ovary and testis. ${ }^{73)}$ Owing to its functional relationship with ApoE, it is a candidate gene for the risk of AD. In addition, several lines of evidence suggested its role in the pathogenesis of AD. It was shown that the CLU expression was elevated in hippocampus, both in AD patients and animal models. ${ }^{74-76)} \mathrm{CLU}$ has a regulatory role in $\mathrm{A} \beta$ metabolism, that it binds to soluble $\mathrm{A} \beta,{ }^{77-80)}$ prevents aggregation of $\mathrm{A} \beta^{79,80)}$ and suppresses $\mathrm{A} \beta$ deposition and modifies $\mathrm{A} \beta$ clearance together with ApoE. ${ }^{81-83)}$ Studies also showed that reduced levels of ApoE and increased levels of CLU were associated with the number of ApoE $\varepsilon 4$ allele, suggesting a compensatory effect of CLU on the reduced level of ApoE. ${ }^{84)}$ The association of CLU polymorphism rs11136000 and the risk of AD was recently identified by two lately published large scale GWASs. ${ }^{50,51)}$ These two papers were followed by other individual genetic association studies, including meta-analysis studies from different cohorts of different populations confirming the association. ${ }^{85-88)}$ A recent study showed association of disease progression and severity of $\mathrm{AD}$ and the plasma concentration of CLU, although they showed no association of the SNP rs11136000 and the risk of AD ${ }^{89)}$ Polymorphism of CLU has also been reported to be associated with serum HDL cholesterol. ${ }^{90)}$ With the similarities of the function of CLU and ApoE and their significant association to the risk of $\mathrm{AD}$, the importance of lipid metabolism and trafficking in brain became an area for research in $\mathrm{AD}$. 


\section{PICALM}

PICALM, encodes the phosphatidylinositol-binding clathrin assembly protein and is mapped on chromosome $11 .^{91)}$ It is ubiquitously expressed and it is highly expressed in neurons. PICALM is involved in clathrin-mediated endocytosis ${ }^{92)}$ and in the fusion of synaptic vesicles to the presynaptic membrane by directing the trafficking of VAMP2 involved in neurotransmitter release. ${ }^{93)}$ The association of genetic variation in PICALM and the risk of AD was first identified through GWAS by Harold et al. ${ }^{50)}$ and the result was further replicated and confirmed by other individual groups and meta-analysis. ${ }^{85,87,88)}$ The SNP rs $3851179,88.5 \mathrm{~kb} 5$ ' to PICALM was associated to the risk of AD. The polymorphism might alter the function of PICALM in synaptic vesicle cycling or endocytic pathways resulting in changes in APP processing and A $\beta$ levels. ${ }^{50)}$ Meta-analysis study by Jun et al. ${ }^{85)}$ showed there was synergistic effects of ApoE and PICALM on AD risk and such synergistic effect was also identified by previous studies investigating interaction of ApoE with PSEN1, ${ }^{94)}$ PSEN2 ${ }^{95)}$ and APP. ${ }^{95,96)}$ In addition, PICALM SNP rs3851179 was associated with hippocampal volume and entorhinal cortex thickness (ECT) ${ }^{97)}$ Biochemical studies showed that PICALM is localized at the endothelial cell of brain and this facilitates the transportation of $\mathrm{A} \beta$ across the blood vessel wall as the major pathway for $\mathrm{A} \beta$ removal. Polymorphisms of PICALM might increase the expression of PICALM and impaired the A $\beta$ removal mechanism, which ultimately causing the development of AD. ${ }^{98)}$

\section{CR1}

CR1 encodes complement component $(3 \mathrm{~b} / 4 \mathrm{~b})$ receptor 1 and is mapped to chromosome 1q32. The hypothesis on the relationship between inflammation/immune response and the development of AD was proposed for decades. Several lines of evidence including activated microglia surrounding A $\beta$ deposits as phagocytic response activated by $\mathrm{A} \beta$ in microglia in a dose- and time-dependent manner, ${ }^{99)}$ the release of various inflammatory mediators after microglia activation, ${ }^{100,101)}$ recruitment of astrocytes to enhance the inflammatory response against $\mathrm{A} \beta$, activation of complement cascade and induction of other inflammatory components such as inducible nitric oxide synthase (iNOS) and cyclooxygenase-2 (COX-2), ${ }^{102,103)}$ suggested microglia and astrocytes are the major players involved in the inflammation process leading to the devel- opment of AD. ${ }^{101,104)}$

CR1 plays an important role in the regulation of complement cascade and clearance of complement components $\mathrm{C} 3 \mathrm{~b}$ and $\mathrm{C} 4 \mathrm{~b} .{ }^{105)}$ Several lines of evidence including activation and bounding of $\mathrm{A} \beta$ by $\mathrm{C} 3 \mathrm{~b},{ }^{106-108)}$ inverse relationship between $\mathrm{C} 3 \mathrm{~b}$ expression and $\mathrm{A} \beta$ deposition $^{109,110)}$ and $\mathrm{C} 3 \mathrm{~b}$ deficiency in APP transgenic mice resulted in $\mathrm{A} \beta$ accumulation and neurodegeneration ${ }^{109)}$ suggested the involvement of $\mathrm{C} 3 \mathrm{~b}$ in the pathogenesis of $\mathrm{AD}$. Since $\mathrm{CR} 1$ is the receptor for $\mathrm{C} 3 \mathrm{~b}$ and a protective role for $\mathrm{CR} 1$ in $\mathrm{AD}$ through the binding of $\mathrm{C} 3 \mathrm{~b}$ and subsequent A $\beta$ clearance was suggested. ${ }^{51,111)}$ A recently published GWAS of AD showed significant association of CR1 polymorphism rs3818361 and the risk of $\mathrm{AD}^{51)}$ and it was replicated and confirmed by other independent studies. ${ }^{85,88)}$ In addition, another CR1 SNP rs1408077 was associated with $\mathrm{ECT},{ }^{97)}$ suggesting the biological relevance of this gene and the risk of AD.

\section{SORL1}

SORL1 encodes sortilin-related receptor 1 and is mapped on chromosome 11q23. SORL1 is a member of the low density lipoprotein receptor family of ApoE receptors in human brain. ${ }^{112)}$ Studies showed that reduced SORL1 expression in AD patients ${ }^{113,114)}$ and human brain cells, ${ }^{115)}$ suggesting the possible relationship of SORL1 and the pathogenesis of AD. It was identified that SORL1 is involved in the processing and trafficking of APP, by binding directly to APP and sorting it into endocytic or recycling pathways, thus influencing A $\beta$ generation. ${ }^{116,117)}$ In the absence of SORL1, APP entered the endosomal pathway and subjected to $\beta$ - and $\gamma$-secretases cleavage and resulted in $\mathrm{A} \beta$ production.

The association of genetic polymorphisms of SORL1 and the risk of $\mathrm{AD}$ was identified ${ }^{118,119)}$ and confirmed in different populations. ${ }^{120-124)}$ In addition, SORL1 was identified in GWAS of $\mathrm{AD}^{125)}$ and provided further evidence of its role in the risk of AD. The first study reporting the association of SORL1 SNPs and the risk of AD was performed in multi-centers setting and they included four different ethnic groups. The authors identified two sets of haplotypes: SNPs in the 5'end and SNPs in the 3' end and their biological study suggested that the genetic variants might modulate the cell-type specific transcription or translation of SORL1 in neurons. ${ }^{119)}$ The association of SNPs in SORL1 and the risk of AD was further confirmed in autopsy-confirmed AD patients. ${ }^{121)}$ Groups using different populations to examine the relationship between SORL1 
and the risk of $\mathrm{AD}$, with four supported the initial findings ${ }^{120,121,126,127)}$ but the other three showed either negative or weak results. ${ }^{122,124,128)}$ One of the studies showed significant association of the SORL1 haplotypes and the risk of AD and also abstract reasoning ability as measured by Similarity test. ${ }^{126)}$ This finding suggested that polymorphisms in SORL1 might be useful in predicting the risk of $\mathrm{AD}$, as well as the severity of the disease or the preclinical symptoms of the disease.

\section{INFLAMMATION-RELATED GENES}

As mentioned in previous section, there is hypothesis for the important role of inflammation in the pathogenesis of $\mathrm{AD}$ and genes involved in the inflammatory pathway are therefore of high interest as the susceptibility genes for AD. Studies showed that microglia surrounding plaques was positive for markers related to inflammation such as MHC class II, COX-2, MCP-1, TNF- $\alpha$, IL- $1 \beta$ and IL-6. ${ }^{104)}$ In addition, elevated levels of chemokines and cytokines and their receptors including IL-1 $\alpha$, CXCR2, CCR3, CCR5 and TGF- $\beta$ were found in post-mortem AD brains. ${ }^{129)}$ Epidemiological studies suggested non-steroidal anti-inflammatory drugs (NSAIDs) might be beneficial in preventing or delaying the onset of $\mathrm{AD},{ }^{130,131)}$ but not reversing the pathology. ${ }^{132)}$ Based on these observations and the on-going studies investigating the relationship between inflammation and $\mathrm{AD}$, it is hypothesized that $\mathrm{A} \beta$ aggregates trigger microglia and astrocytes, leading to local inflammation and further activate the immune response. This resulted in the activation of inflammatory mediators such as TNF- $\alpha$, IL- $1 \beta$ and IL-6, causing neuronal cell death and further activates microglia and astrocytes, formed a vicious cycle of inflammatory response. ${ }^{133-135)}$

There were many genetic association studies investigating the relationship of polymorphisms of inflammatory-related genes including TNF- $\alpha$, IL- $1 \beta$, IL-6, IL-10, TLR-4 and COX-2 and the risk of AD. In addition, among the top 10 genes as listed in AlzGene, two of them are involved in the inflammatory pathway (CR1 and IL-8), suggesting the possible implication of inflammation in the pathogenesis of AD. Different TNF- $\alpha$ SNPs $(-238,-308,-850,-863$ and -1031) were investigated in genetic association studies and TNF-238, -863 and -1031 were reported to modulate the transcriptional activity of TNF- $\alpha$ gene and to be associated with risk of AD, with population specificity. ${ }^{46,47,136-141)}$ AlzGene meta-analysis showed that TNF-1031 was significantly associated with the risk of $\mathrm{AD}$, giving odds ratio of 1.35 (95\% CI: 1.04-1.77). IL-1 $\beta-511$ and IL-1 $\beta$-3953 were the most widely studied SNPs in IL-1 $\beta$ for the risk of AD. However, the results of the published genetic association studies on the relationship between IL-1 $\beta$ and the risk of AD are still inconclusive. ${ }^{142-158)}$ AlzGene meta-analysis showed that both SNPs were significantly associated with the risk of $\mathrm{AD}$ and another meta-analysis study confirmed the association of IL-1 $\beta-3953$ but not IL-1 $\beta-511$. $^{33,159)}$ Di Bona et $a{ }^{44)}$ showed a remarkable heterogeneity among studies for IL-1 $\beta-511$, therefore sub- group (Caucasians) meta-analysis was performed and yielded significant association to the risk of $\mathrm{AD}$, with $\mathrm{OR}$ of 1.32 (95\% CI: 1.03-1.69). ${ }^{44)}$ This finding suggested that there is hidden population stratification for some SNPs in the association to the risk of the trait and it is important to control for these variants for the data analysis.

Many groups performed genetic association studies on IL- 6 and the risk of AD. The common SNPs for IL-6 being studied included $-572,-174$ and variable number tandem repeat (VNTR) polymorphism but there was no confirmed association. ${ }^{160-167)}$ Interestingly, some studies showed no association of genetic polymorphisms on IL-6 and the risk of AD alone, but observed significantly increased risk of $\mathrm{AD}$ when combined with certain genotypes at other genes such as TNF- $\alpha$ and IL-10, suggesting there might be interaction effect between genes in modulating the risk of AD. ${ }^{168-170)}$ IL-10 is an anti-inflammatory gene and several groups reported association of IL-10 polymorphisms and the risk of $\mathrm{AD}^{171-175)}$ but the association is inconclusive with some studies reporting negative results. $^{47,128,139,176-178)}$ IL-10 polymorphisms were associated with IL-10 levels ${ }^{175,179)}$ and clinical progression of AD, ${ }^{180)}$ suggesting its possible function as genetic marker for predicting disease progression. COX-2 is also at the top list of the inflammation-related genes implicating in the risk of $\mathrm{AD}$, based on its important role in the pathophysiological process of inflammatory disease. Polymorphisms of COX-2 $(-2319,-765$, Ex 10+837) were associated with the risk of $\mathrm{AD}^{181-183)}$ and the use of COX-2 inhibitors has been suggested for treatment of AD. ${ }^{184,185)}$

The advantage of using genetic marker for inflammatory genes in determining the risk of $\mathrm{AD}$ over measuring the level of inflammatory cytokines such as IL-1, IL-6, IL-10 or TNF- $\alpha$, is the measurement will be less likely to be affected by the daily fluctuation. Several studies suggested that the increased level of inflammatory cytokines is associated with increased risk of AD. On the other hand, several genetic markers were associated with 
the predisposition of increased inflammatory cytokine levels. Therefore, it might be possible to predict one's risk of getting $\mathrm{AD}$ by genotyping those inflammatory genetic markers.

As observed in other common diseases, the SNPs associated with the risk of AD conferred a small effect to the risk of $\mathrm{AD}$, giving the relative risk of the disease to the order of 1.1 to 2.0 and odds ratio rarely exceeding $3 .^{33,186)}$ For example, it is estimated the attributable fraction for ApoE was $25.5 \%$, CLU was $8.9 \%$ and CR1 was $4 \% .^{51,111)}$ Since $\mathrm{AD}$ is a complex disease and it is expected to be affected by multiple genes and polymorphisms, with each contributing a small effect on the disease risk. On the other hand, gene-gene interaction effect for the risk of $\mathrm{AD}$ was observed in a number of genes such as IL-1, IL-10 and TNF- $\alpha,{ }^{168-170)}$ testing multiple SNPs that were associated with the risk of $\mathrm{AD}$ might provide more information in the prediction. ${ }^{187)}$ Studies in other common diseases such as diabetes also suggested the use of multiple gene loci to predict disease risks. ${ }^{188)}$ Genetic profiling, by incorporating a panel of established genetic susceptibility factors to estimate one's risk to a disease might be useful in providing a more accurate diagnosis. ${ }^{189)}$ Each susceptibility locus contributed to the genetic risk score can be added up and weighed differently based on its prevalence and relative risk to the disease. For example, the genotype of ApoE is expected to be weighted more in the risk score. A cut-off score can then be determined base on the results of previous studies and algorithm to estimate the risk of the disease. In $\mathrm{AD}$, genes showing significant association in GWASs of $\mathrm{AD}$, inflammatory genes and ApoE will be promising candidate genes for the panel in genetic profiling for diagnosis of AD or predicting one's risk of conversion from MCI to AD. However, this approach is limited by the restricted predictive value of genetic markers in complex disease and by the interaction effect of environmental influences such as exposure to different environmental factors and epigenetic changes on the onset and progression of the disease. At this stage, genetic profiling will not be adequate for the diagnosis of AD but it might improve the accuracy and specificity of diagnosis in addition to the present clinical diagnosis and imaging techniques and possibly applied in the identification of pre-symptomatic AD patients.

In conclusion, a large collaborative efforts will be required to explore the genetic variations, including structural variation and epigenetic, in addition to the statistical algorithms to estimate the contribution of each susceptibility polymorphism to the overall disease risk of AD.
Further research efforts are necessary to find out if in the future, genetic profiling in addition to the current clinical diagnosis might be useful in identifying subjects with high risk of $\mathrm{AD}$ predisposition and ultimately lead to early diagnosis and intervention of the disease.

\section{REFERENCES}

1. Ferri CP, Sousa R, Albanese E, Ribeiro WS, Honyashiki M. Alzheimer's Disease International World Alzheimer Report 2009, Alzheimer's Disease International, London, 2009.

2. Petersen RC. Mild cognitive impairment as a diagnostic entity. J Intern Med 2004;256:183-194.

3. Petersen RC, Smith GE, Waring SC, Ivnik RJ, Tangalos EG, Kokmen E. Mild cognitive impairment: clinical characterization and outcome. Arch Neurol 1999;56: 303-308.

4. Petersen RC, Stevens JC, Ganguli M, Tangalos EG, Cummings JL, DeKosky ST. Practice parameter: early detection of dementia: mild cognitive impairment (an evidence-based review). Report of the Quality Standards Subcommittee of the American Academy of Neurology. Neurology 2001;56:1133-1142.

5. Perrin RJ, Fagan AM, Holtzman DM. Multimodal techniques for diagnosis and prognosis of Alzheimer's disease. Nature 2009;461:916-922.

6. Bird TD. Genetic aspects of Alzheimer disease. Genet Med 2008;10:231-239.

7. McKhann G, Drachman D, Folstein M, Katzman R, Price D, Stadlan EM. Clinical diagnosis of Alzheimer's disease: report of the NINCDS-ADRDA Work Group under the auspices of Department of Health and Human Services Task Force on Alzheimer's Disease. Neurology 1984;34: 939-944.

8. Lopez OL, Swihart AA, Becker JT, Reinmuth OM, Reynolds CF 3rd, Rezek DL, et al. Reliability of NINCDSADRDA clinical criteria for the diagnosis of Alzheimer's disease. Neurology 1990;40:1517-1522.

9. Schofield PW, Tang M, Marder K, Bell K, Dooneief G, Lantigua $\mathrm{R}$, et al. Consistency of clinical diagnosis in a community-based longitudinal study of dementia and Alzheimer's disease. Neurology 1995;45:2159-2164.

10. Andreasen N, Minthon L, Clarberg A, Davidsson P, Gottfries J, Vanmechelen E, et al. Sensitivity, specificity, and stability of CSF-tau in $A D$ in a community-based patient sample. Neurology 1999;53:1488-1494.

11. Arai H, Terajima M, Miura M, Higuchi S, Muramatsu T, Machida N, et al. Tau in cerebrospinal fluid: a potential diagnostic marker in Alzheimer's disease. Ann Neurol 1995;38:649-652.

12. Blennow K, Vanmechelen E, Hampel H. CSF total tau, Abeta42 and phosphorylated tau protein as biomarkers for Alzheimer's disease. Mol Neurobiol 2001;24:87-97.

13. Galasko D. CSF tau and Abeta42: logical biomarkers for Alzheimer's disease? Neurobiol Aging 1998;19:117-119.

14. Sunderland T, Linker G, Mirza N, Putnam KT, Friedman $\mathrm{DL}$, Kimmel LH, et al. Decreased beta-amyloidl-42 and increased tau levels in cerebrospinal fluid of patients with Alzheimer disease. JAMA 2003;289:2094-2103.

15. Grunberg J, Walter J, Loetscher H, Deuschle U, Jacobsen $\mathrm{H}$, Haass C. Alzheimer's disease associated presenilin-1 holoprotein and its 18-20 kDa C-terminal fragment are 
death substrates for proteases of the caspase family. Biochemistry 1998;37:2263-2270.

16. Motter R, Vigo-Pelfrey C, Kholodenko D, Barbour R, Johnson-Wood K, Galasko D, et al. Reduction of betaamyloid peptide42 in the cerebrospinal fluid of patients with Alzheimer's disease. Ann Neurol 1995;38:643-648.

17. Olsson A, Vanderstichele H, Andreasen N, De Meyer G, Wallin A, Holmberg B, et al. Simultaneous measurement of beta-amyloid (1-42), total tau, and phosphorylated tau (Thr181) in cerebrospinal fluid by the xMAP technology. Clin Chem 2005;51:336-345.

18. Vanderstichele H, De Vreese K, Blennow K, Andreasen N, Sindic C, Ivanoiu A, et al. Analytical performance and clinical utility of the INNOTEST PHOSPHO-TAU (181P) assay for discrimination between Alzheimer's disease and dementia with Lewy bodies. Clin Chem Lab Med 2006; 44:1472-1480.

19. Blennow K. Cerebrospinal fluid protein biomarkers for Alzheimer's disease. NeuroRx 2004;1:213-225.

20. Green AJ, Harvey RJ, Thompson EJ, Rossor MN. Increased tau in the cerebrospinal fluid of patients with frontotemporal dementia and Alzheimer's disease. Neurosci Lett 1999;259:133-135.

21. Kohnken R, Buerger K, Zinkowski R, Miller C, Kerkman $\mathrm{D}$, DeBernardis J, et al. Detection of tau phosphorylated at threonine 231 in cerebrospinal fluid of Alzheimer's disease patients. Neurosci Lett 2000;287:187-190.

22. Hampel H, Buerger K, Zinkowski R, Teipel SJ, Goernitz A, Andreasen N, et al. Measurement of phosphorylated tau epitopes in the differential diagnosis of Alzheimer disease: a comparative cerebrospinal fluid study. Arch Gen Psychiatry 2004;61:95-102.

23. Consensus report of the Working Group on: "Molecular and Biochemical Markers of Alzheimer's Disease". The Ronald and Nancy Reagan Research Institute of the Alzheimer's Association and the National Institute on Aging Working Group. Neurobiol Aging 1998;19:109-116.

24. Vemuri P, Wiste HJ, Weigand SD, Shaw LM, Trojanowski $\mathrm{JQ}$, Weiner MW, et al. MRI and CSF biomarkers in normal, MCI, and AD subjects: predicting future clinical change. Neurology 2009;73:294-301.

25. Whitwell JL, Josephs KA, Murray ME, Kantarci K, Przybelski SA, Weigand SD, et al. MRI correlates of neurofibrillary tangle pathology at autopsy: a voxel-based morphometry study. Neurology 2008;71:743-749.

26. Thompson PM, Hayashi KM, de Zubicaray G, Janke AL, Rose SE, Semple J, et al. Dynamics of gray matter loss in Alzheimer's disease. J Neurosci 2003;23:994-1005.

27. Scahill RI, Schott JM, Stevens JM, Rossor MN, Fox NC. Mapping the evolution of regional atrophy in Alzheimer's disease: unbiased analysis of fluid-registered serial MRI. Proc Natl Acad Sci USA 2002;99:4703-4707.

28. Adalsteinsson E, Sullivan EV, Kleinhans N, Spielman DM, Pfefferbaum A. Longitudinal decline of the neuronal marker N-acetyl aspartate in Alzheimer's disease. Lancet 2000;355:1696-1697.

29. Klunk WE, Engler H, Nordberg A, Wang Y, Blomqvist G, Holt DP, et al. Imaging brain amyloid in Alzheimer's disease with Pittsburgh Compound-B. Ann Neurol 2004; 55:306-319.

30. Jack CR Jr, Lowe VJ, Senjem ML, Weigand SD, Kemp $\mathrm{BJ}$, Shiung MM, et al. $11 \mathrm{CPiB}$ and structural MRI provide complementary information in imaging of Alzheimer's disease and amnestic mild cognitive impairment. Brain 2008;131:665-680.
31. Villemagne VL, Pike KE, Darby D, Maruff P, Savage G, $\mathrm{Ng} \mathrm{S}$, et al. Abeta deposits in older non-demented individuals with cognitive decline are indicative of preclinical Alzheimer's disease. Neuropsychologia 2008;46:16881697.

32. Poirier J, Davignon J, Bouthillier D, Kogan S, Bertrand P, Gauthier S. Apolipoprotein E polymorphism and Alzheimer's disease. Lancet 1993;342:697-699.

33. Bertram L, McQueen MB, Mullin K, Blacker D, Tanzi RE. Systematic meta-analyses of Alzheimer disease genetic association studies: the AlzGene database. Nat Genet 2007; 39:17-23.

34. Corder EH, Saunders AM, Strittmatter WJ, Schmechel DE, Gaskell PC, Small GW, et al. Gene dose of apolipoprotein E type 4 allele and the risk of Alzheimer's disease in late onset families. Science 1993;261:921-923.

35. Pericak-Vance MA, Bebout JL, Gaskell PC Jr, Yamaoka LH, Hung WY, Alberts MJ, et al. Linkage studies in familial Alzheimer disease: evidence for chromosome 19 linkage. Am J Hum Genet 1991;48:1034-1050.

36. Blacker D, Bertram L, Saunders AJ, Moscarillo TJ, Albert MS, Wiener $\mathrm{H}$, et al. Results of a high-resolution genome screen of 437 Alzheimer's disease families. Hum Mol Genet 2003; 12:23-32.

37. Wijsman EM, Daw EW, Yu CE, Payami H, Steinbart EJ, Nochlin D, et al. Evidence for a novel late-onset Alzheimer disease locus on chromosome 19 p13.2. Am J Hum Genet 2004;75:398-409.

38. Lee JH, Mayeux R, Mayo D, Mo J, Santana V, Williamson $\mathrm{J}$, et al. Fine mapping of $10 q$ and $18 q$ for familial Alzheimer's disease in Caribbean Hispanics. Mol Psychiatry 2004;9:1042-1051.

39. Hiltunen M, Mannermaa A, Thompson D, Easton D, Pirskanen M, Helisalmi S, et al. Genome-wide linkage disequilibrium mapping of late-onset Alzheimer's disease in Finland. Neurology 2001;57:1663-1668.

40. Zubenko GS, Hughes HB, Stiffler JS, Hurtt MR, Kaplan BB. A genome survey for novel Alzheimer disease risk loci: results at 10-cM resolution. Genomics 1998;50:121-128.

41. Pericak-Vance MA, Bass MP, Yamaoka LH, Gaskell PC, Scott WK, Terwedow HA, et al. Complete genomic screen in late-onset familial Alzheimer disease. Evidence for a new locus on chromosome 12. JAMA 1997;278:1237-1241.

42. Mayeux R, Lee JH, Romas SN, Mayo D, Santana V, Williamson J, et al. Chromosome-12 mapping of late-onset Alzheimer disease among Caribbean Hispanics. Am J Hum Genet 2002;70:237-243.

43. Collins JS, Perry RT, Watson B Jr, Harrell LE, Acton RT, Blacker D, et al. Association of a haplotype for tumor necrosis factor in siblings with late-onset Alzheimer disease: the NIMH Alzheimer Disease Genetics Initiative. Am J Med Genet 2000;96:823-830.

44. Di Bona D, Candore G, Franceschi C, Licastro F, Colonna-Romano G, Cammà $\mathrm{C}$, et al. Systematic review by meta-analyses on the possible role of TNF-alpha polymorphisms in association with Alzheimer's disease. Brain Res Rev 2009;61:60-68.

45. Laws SM, Perneczky R, Wagenpfeil S, Muüller U, Forstl $\mathrm{H}$, Martins RN, et al. TNF polymorphisms in Alzheimer disease and functional implications on CSF beta-amyloid levels. Hum Mutat 2005;26:29-35.

46. Ma SL, Tang NL, Lam LC, Chiu HF. Association between tumor necrosis factor-alpha promoter polymorphism and Alzheimer's disease. Neurology 2004;62:307-309.

47. Ramos EM, Lin MT, Larson EB, Maezawa I, Tseng LH, 
Edwards KL, et al. Tumor necrosis factor alpha and interleukin 10 promoter region polymorphisms and risk of late-onset Alzheimer disease. Arch Neurol 2006;63:11651169.

48. International HapMap Consortium. The international HapMap project. Nature 2003;426:789-796.

49. McCarthy MI, Abecasis GR, Cardon LR, Goldstein DB, Little J, Ioannidis JP, et al. Genome-wide association studies for complex traits: consensus, uncertainty and challenges. Nat Rev Genet 2008;9:356-369.

50. Harold D, Abraham R, Hollingworth P, Sims R, Gerrish A, Hamshere ML, et al. Genome-wide association study identifies variants at CLU and PICALM associated with Alzheimer's disease. Nat Genet 2009;41:1088-1093.

51. Lambert JC, Heath S, Even G, Campion D, Sleegers K, Hiltunen M, et al. Genome-wide association study identifies variants at CLU and CRI associated with Alzheimer's disease. Nat Genet 2009;41:1094-1099.

52. Meyer JM, Breitner JC. Multiple threshold model for the onset of Alzheimer's disease in the NAS-NRC twin panel. Am J Med Genet 1998;81:92-97.

53. Teslovich TM, Musunuru K, Smith AV, Edmondson AC, Stylianou IM, Koseki M, et al. Biological, clinical and population relevance of 95 loci for blood lipids. Nature 2010;466:707-713.

54. Siest G, Pillot T, Régis-Bailly A, Leininger-Muller B, Steinmetz J, Galteau MM, et al. Apolipoprotein E: an important gene and protein to follow in laboratory medicine. Clin Chem 1995;41:1068-1086.

55. Gomez-Isla T, West HL, Rebeck GW, Harr SD, Growdon $\mathrm{JH}$, Locascio JJ, et al. Clinical and pathological correlates of apolipoprotein E epsilon 4 in Alzheimer's disease. Ann Neurol 1996;39:62-70.

56. Holmes C, Levy R, McLoughlin DM, Powell JF, Lovestone S. Apolipoprotein E: non-cognitive symptoms and cognitive decline in late onset Alzheimer's disease. $J$ Neurol Neurosurg Psychiatry 1996;61:580-583.

57. Hyman BT, Gomez-Isla T, Rebeck GW, Briggs M, Chung $\mathrm{H}$, West HL, et al. Epidemiological, clinical, and neuropathological study of apolipoprotein $E$ genotype in Alzheimer's disease. Ann N Y Acad Sci 1996;802:1-5.

58. Kurz A, Altland K, Lautenschlager N, Zimmer R, Busch $\mathrm{R}$, Gerundt I, et al. Apolipoprotein E type 4 allele and Alzheimer's disease: effect on age at onset and relative risk in different age groups. J Neurol 1996;243:452-456.

59. Slooter AJ, Cruts M, Kalmijn S, Hofman A, Breteler MM, Van Broeckhoven C, et al. Risk estimates of dementia by apolipoprotein $E$ genotypes from a population-based incidence study: the Rotterdam Study. Arch Neurol 1998;55:964-968.

60. Guerreiro RJ, Gustafson DR, Hardy J. The genetic architecture of Alzheimer's disease: beyond APP, PSENs and APOE. Neurobiol Aging 2010. [Epub ahead of print].

61. Strittmatter WJ, Weisgraber KH, Huang DY, Dong LM, Salvesen GS, Pericak-Vance M, et al. Binding of human apolipoprotein $E$ to synthetic amyloid beta peptide: isoform-specific effects and implications for late-onset Alzheimer disease. Proc Natl Acad Sci U S A 1993;90: 8098-8102.

62. Strittmatter WJ, Weisgraber KH, Goedert M, Saunders AM, Huang D, Corder EH, et al. Hypothesis: microtubule instability and paired helical filament formation in the Alzheimer disease brain are related to apolipoprotein $E$ genotype. Exp Neurol 1994;125:163-171.

63. Namba Y, Tomonaga M, Kawasaki H, Otomo E, Ikeda K.
Apolipoprotein E immunoreactivity in cerebral amyloid deposits and neurofibrillary tangles in Alzheimer's disease and kuru plaque amyloid in Creutzfeldt-Jakob disease. Brain Res 1991;541:163-166.

64. Sanan DA, Weisgraber KH, Russell SJ, Mahley RW, Huang D, Saunders A, et al. Apolipoprotein E associates with beta amyloid peptide of Alzheimer's disease to form novel monofibrils. Isoform apoE4 associates more efficiently than apoE3. J Clin Invest 1994;94:860-869.

65. Myers RH, Schaefer EJ, Wilson PW, D'Agostino R, Ordovas JM, Espino A, et al. Apolipoprotein E epsilon4 association with dementia in a population-based study: the Framingham study. Neurology 1996;46:673-677.

66. Zannis VI, Just PW, Breslow JL. Human apolipoprotein E isoprotein subclasses are genetically determined. Am J Hum Genet 1981;33:11-24.

67. Saunders AM, Hulette O, Welsh-Bohmer KA, Schmechel $\mathrm{DE}$, Crain B, Burke JR, et al. Specificity, sensitivity, and predictive value of apolipoprotein-E genotyping for sporadic Alzheimer's disease. Lancet 1996;348:90-93.

68. Mayeux R, Saunders AM, Shea S, Mirra S, Evans D, Roses $\mathrm{AD}$, et al. Utility of the apolipoprotein $E$ genotype in the diagnosis of Alzheimer's disease. Alzheimer's disease centers consortium on apolipoprotein $E$ and Alzheimer's disease. N Engl J Med 1998;338:506-511.

69. Slooter AJ, Breteler MB, Ott A, Van Broeckhoven C, van Duijn CM. APOE genotyping in differential diagnosis of Alzheimer's disease. Lancet 1996;348:334.

70. Kakulas BA, Wilton SD, Fabian VA, Jones TM. Apolipoprotein-E genotyping in diagnosis of Alzheimer's disease. Lancet 1996;348:483.

71. Tsuang D, Larson EB, Bowen J, McCormick W, Teri L, Nochlin D, et al. The utility of apolipoprotein E genotyping in the diagnosis of Alzheimer disease in a community-based case series. Arch Neurol 1999;56:1489-1495.

72. Farrer LA, Cupples LA, van Duijn CM, Kurz A, Zimmer $\mathrm{R}$, Muüller $\mathrm{U}$, et al. Apolipoprotein $E$ genotype in patients with Alzheimer's disease: implications for the risk of dementia among relatives. Ann Neurol 1995;38:797-808.

73. de Silva HV, Stuart WD, Duvic CR, Wetterau JR, Ray MJ, Ferguson DG, et al. A 70-kDa apolipoprotein designated ApoJ is a marker for subclasses of human plasma high density lipoproteins. J Biol Chem 1990;265:13240-13247.

74. May PC, Lampert-Etchells M, Johnson SA, Poirier J, Masters JN, Finch CE. Dynamics of gene expression for a hippocampal glycoprotein elevated in Alzheimer's disease and in response to experimental lesions in rat. Neuron 1990;5:831-839.

75. Duguid JR, Bohmont CW, Liu NG, Tourtellotte WW. Changes in brain gene expression shared by scrapie and Alzheimer disease. Proc Natl Acad Sci U S A 1989;86: 7260-7264.

76. Oda T, Pasinetti GM, Osterburg HH, Anderson C, Johnson SA, Finch CE. Purification and characterization of brain clusterin. Biochem Biophys Res Commun 1994;204:11311136.

77. Boggs LN, Fuson KS, Baez M, Churgay L, McClure D, Becker $\mathrm{G}$, et al. Clusterin (Apo J) protects against in vitro amyloid-beta (1-40) neurotoxicity. J Neurochem 1996;67: 1324-1327.

78. DeMattos RB, O'Dell MA, Parsadanian M, Taylor JW, Harmony JA, Bales KR, et al. Clusterin promotes amyloid plaque formation and is critical for neuritic toxicity in a mouse model of Alzheimer's disease. Proc Natl Acad Sci U S A 2002;99:10843-10848. 
79. Matsubara E, Soto C, Governale S, Frangione B, Ghiso J. Apolipoprotein $J$ and Alzheimer's amyloid beta solubility. Biochem J 1996;316:671-679.

80. Oda T, Wals P, Osterburg HH, Johnson SA, Pasinetti GM, Morgan TE, et al. Clusterin (apoJ) alters the aggregation of amyloid beta-peptide (A beta 1-42) and forms slowly sedimenting $A$ beta complexes that cause oxidative stress. Exp Neurol 1995;136:22-31.

81. DeMattos RB, Cirrito JR, Parsadanian M, May PC, O'Dell MA, Taylor JW, et al. ApoE and clusterin cooperatively suppress Abeta levels and deposition: evidence that ApoE regulates extracellular Abeta metabolism in vivo. Neuron 2004;41:193-202.

82. Bell RD, Sagare AP, Friedman AE, Bedi GS, Holtzman $\mathrm{DM}$, Deane R, et al. Transport pathways for clearance of human Alzheimer's amyloid beta-peptide and apolipoproteins $E$ and $J$ in the mouse central nervous system. $J$ Cereb Blood Flow Metab 2007;27:909-918.

83. Nuutinen T, Suuronen T, Kauppinen A, Salminen A. Clusterin: a forgotten player in Alzheimer's disease. Brain Res Rev 2009;61:89-104.

84. Bertrand P, Poirier J, Oda T, Finch CE, Pasinetti GM. Association of apolipoprotein $E$ genotype with brain levels of apolipoprotein $E$ and apolipoprotein $J$ (clusterin) in Alzheimer disease. Brain Res Mol Brain Res 1995;33: 174-178

85. Jun G, Naj AC, Beecham GW, Wang LS, Buros J, Gallins $\mathrm{PJ}$, et al. Meta-analysis confirms CR1, CLU, and PICALM as alzheimer disease risk loci and reveals interactions with APOE genotypes. Arch Neurol 2010;67:1473-1484.

86. Corneveaux JJ, Myers AJ, Allen AN, Pruzin JJ, Ramirez $\mathrm{M}$, Engel A, et al. Association of CRl, CLU and PICALM with Alzheimer's disease in a cohort of clinically characterized and neuropathologically verified individuals. Hum Mol Genet 2010;19:3295-3301.

87. Seshadri S, Fitzpatrick AL, Ikram MA, DeStefano AL, Gudnason V, Boada $\mathrm{M}$, et al. Genome-wide analysis of genetic loci associated with Alzheimer disease. JAMA 2010;303:1832-1840.

88. Carrasquillo MM, Belbin O, Hunter TA, Ma L, Bisceglio $\mathrm{GD}$, Zou F, et al. Replication of CLU, CRI, and PICALM associations with alzheimer disease. Arch Neurol 2010;67: 961-964.

89. Thambisetty M, Simmons A, Velayudhan L, Hye A, Campbell J, Zhang Y, et al. Association of plasma clusterin concentration with severity, pathology, and progression in Alzheimer disease. Arch Gen Psychiatry 2010;67:739-748.

90. Nestlerode CS, Bunker CH, Sanghera DK, Aston CE, Ukoli FA, Kamboh MI. Apolipoprotein $J$ polymorphisms and serum HDL cholesterol levels in African blacks. Hum Biol 1999;71:197-218.

91. Tebar F, Bohlander SK, Sorkin A. Clathrin assembly lymphoid myeloid leukemia (CALM) protein: localization in endocytic-coated pits, interactions with clathrin, and the impact of overexpression on clathrin-mediated traffic. Mol Biol Cell 1999;10:2687-2702.

92. Kim JA, Kim HL. Cell-free expression and functional reconstitution of CALM in clathrin assembly. Exp Mol Med 2001;33:89-94.

93. Harel A, Wu F, Mattson MP, Morris CM, Yao PJ. Evidence for CALM in directing VAMP2 trafficking. Traffic 2008;9:417-429.

94. Pastor P, Roe CM, Villegas A, Bedoya G, Chakraverty S, Garcia G, et al. Apolipoprotein Eepsilon4 modifies Alzheimer's disease onset in an E280A PS1 kindred. Ann Neurol
2003;54:163-169.

95. Wijsman EM, Daw EW, Yu X, Steinbart EJ, Nochlin D, Bird TD, et al. APOE and other loci affect age-at-onset in Alzheimer's disease families with PS2 mutation. Am J Med Genet B Neuropsychiatr Genet 2005;132B:14-20.

96. St George-Hyslop P, McLachlan DC, Tsuda T, Rogaev E, Karlinsky H, Lippa CF, et al. Alzheimer's disease and possible gene interaction. Science 1994;263:537.

97. Biffi A, Anderson CD, Desikan RS, Sabuncu M, Cortellini $\mathrm{L}$, Schmansky N, et al. Genetic variation and neuroimaging measures in Alzheimer disease. Arch Neurol 2010;67: 677-685.

98. Baig S, Joseph SA, Tayler H, Abraham R, Owen MJ, Williams J, et al. Distribution and expression of picalm in Alzheimer disease. J Neuropathol Exp Neurol 2010;69: 1071-1077.

99. Kopec KK, Carroll RT. Alzheimer's beta-amyloid peptide 1-42 induces a phagocytic response in murine microglia. J Neurochem 1998;71:2123-2131.

100. Heneka MT, O'Banion MK. Inflammatory processes in Alzheimer's disease. J Neuroimmunol 2007;184:69-91.

101. Tuppo EE, Arias HR. The role of inflammation in Alzheimer's disease. Int J Biochem Cell Biol 2005;37: 289-305.

102. Farfara D, Lifshitz V, Frenkel D. Neuroprotective and neurotoxic properties of glial cells in the pathogenesis of Alzheimer's disease. J Cell Mol Med 2008;12:762-780.

103. Sastre M, Klockgether T, Heneka MT. Contribution of inflammatory processes to Alzheimer's disease: molecular mechanisms. Int J Dev Neurosci 2006;24:167-176.

104. Akiyama H, Barger S, Barnum S, Bradt B, Bauer J, Cole $\mathrm{GM}$, et al. Inflammation and Alzheimer's disease. Neurobiol Aging 2000;21:383-421.

105. Khera R, Das N. Complement Receptor 1: disease associations and therapeutic implications. Mol Immunol 2009;46: 761-772.

106. Kuo YM, Kokjohn TA, Kalback W, Luehrs D, Galasko $\mathrm{DR}$, Chevallier $\mathrm{N}$, et al. Amyloid-beta peptides interact with plasma proteins and erythrocytes: implications for their quantitation in plasma. Biochem Biophys Res Commun 2000;268:750-756.

107. Rogers J, Li R, Mastroeni D, Grover A, Leonard B, Ahern $\mathrm{G}$, et al. Peripheral clearance of amyloid beta peptide by complement C3-dependent adherence to erythrocytes. Neurobiol Aging 2006;27:1733-1739.

108. Webster S, Bradt B, Rogers J, Cooper N. Aggregation state-dependent activation of the classical complement pathway by the amyloid beta peptide. J Neurochem 1997;69:388-398.

109. Wyss-Coray T, Yan F, Lin AH, Lambris JD, Alexander JJ, Quigg RJ, et al. Prominent neurodegeneration and increased plaque formation in complement-inhibited Alzheimer's mice. Proc Natl Acad Sci USA 2002;99:10837-10842.

110. Zhou J, Fonseca MI, Pisalyaput K, Tenner AJ. Complement $C 3$ and $C 4$ expression in Clq sufficient and deficient mouse models of Alzheimer's disease. J Neurochem 2008;106: 2080-2092.

111. Sleegers K, Lambert JC, Bertram L, Cruts M, Amouyel P, Van Broeckhoven C. The pursuit of susceptibility genes for Alzheimer's disease: progress and prospects. Trends Genet 2010;26:84-93.

112. Motoi Y, Aizawa T, Haga S, Nakamura S, Namba Y, Ikeda K. Neuronal localization of a novel mosaic apolipoprotein E receptor, LR11, in rat and human brain. Brain Res 1999;833:209-215. 
113. Dodson SE, Gearing M, Lippa CF, Montine TJ, Levey AI, Lah JJ. LR11/SorLA expression is reduced in sporadic Alzheimer disease but not in familial Alzheimer disease. $J$ Neuropathol Exp Neurol 2006;65:866-872.

114. Scherzer CR, Offe K, Gearing M, Rees HD, Fang G, Heilman CJ, et al. Loss of apolipoprotein E receptor LR11 in Alzheimer disease. Arch Neurol 2004;61:1200-1205.

115. Zhao Y, Cui JG, Lukiw WJ. Reduction of sortilin-1 in Alzheimer hippocampus and in cytokine-stressed human brain cells. Neuroreport 2007;18:1187-1191.

116. Andersen OM, Reiche J, Schmidt V, Gotthardt M, Spoelgen R, Behlke J, et al. Neuronal sorting protein-related receptor sorLA/LR11 regulates processing of the amyloid precursor protein. Proc Natl Acad Sci USA 2005;102: 13461-13466.

117. Offe K, Dodson SE, Shoemaker JT, Fritz JJ, Gearing M, Levey AI, et al. The lipoprotein receptor LR11 regulates amyloid beta production and amyloid precursor protein traffic in endosomal compartments. J Neurosci 2006;26: 1596-1603.

118. Lee JH, Cheng R, Schupf N, Manly J, Lantigua R, Stern $\mathrm{Y}$, et al. The association between genetic variants in SORL1 and Alzheimer disease in an urban, multiethnic, community-based cohort. Arch Neurol 2007;64:501-506.

119. Rogaeva E, Meng Y, Lee JH, Gu Y, Kawarai T, Zou F, et al. The neuronal sortilin-related receptor SORL1 is genetically associated with Alzheimer disease. Nat Genet 2007:39:168-177.

120. Bettens K, Brouwers N, Engelborghs S, De Deyn PP, Van Broeckhoven C, Sleegers K. SORL1 is genetically associated with increased risk for late-onset Alzheimer disease in the Belgian population. Hum Mutat 2008;29: 769-770.

121. Lee JH, Cheng R, Honig LS, Vonsattel JP, Clark L, Mayeux R. Association between genetic variants in SORL1 and autopsy-confirmed Alzheimer disease. Neurology 2008; 70:887-889.

122. Li Y, Rowland C, Catanese J, Morris J, Lovestone S, O'Donovan MC, et al. SORL1 variants and risk of late-onset Alzheimer's disease. Neurobiol Dis 2008;29: 293-296.

123. Meng Y, Lee JH, Cheng R, St George-Hyslop P, Mayeux R, Farrer LA. Association between SORL1 and Alzheimer's disease in a genome-wide study. Neuroreport 2007;18: 1761-1764.

124. Webster JA, Myers AJ, Pearson JV, Craig DW, Hu-Lince $\mathrm{D}$, Coon KD, et al. Sorll as an Alzheimer's disease predisposition gene? Neurodegener Dis 2008;5:60-64.

125. Feulner TM, Laws SM, Friedrich P, Wagenpfeil S, Wurst $\mathrm{SH}$, Riehle $\mathrm{C}$, et al. Examination of the current top candidate genes for $A D$ in a genome-wide association study. Mol Psychiatry 2010;15:756-766.

126. Seshadri S, DeStefano AL, Au R, Massaro JM, Beiser AS, Kelly-Hayes M, et al. Genetic correlates of brain aging on MRI and cognitive test measures: a genome-wide association and linkage analysis in the Framingham Study. BMC Med Genet 2007;8 Suppl 1:S15.

127. Tan EK, Lee J, Chen CP, Teo YY, Zhao Y, Lee WL. SORL1 haplotypes modulate risk of Alzheimer's disease in Chinese. Neurobiol Aging 2009;30:1048-1051.

128. Li H, Wetten S, Li L, St Jean PL, Upmanyu R, Surh L, et al. Candidate single-nucleotide polymorphisms from a genomewide association study of Alzheimer disease. Arch Neurol 2008;65:45-53.

129. Cartier L, Hartley O, Dubois-Dauphin M, Krause KH.
Chemokine receptors in the central nervous system: role in brain inflammation and neurodegenerative diseases. Brain Res Brain Res Rev 2005;48:16-42.

130. Szekely CA, Zandi PP. Non-steroidal anti-inflammatory drugs and Alzheimer's disease: the epidemiological evidence. CNS Neurol Disord Drug Targets 2010;9:132-139.

131. Lim GP, Yang F, Chu T, Chen P, Beech W, Teter B, et al. Ibuprofen suppresses plaque pathology and inflammation in a mouse model for Alzheimer's disease. J Neurosci 2000;20:5709-5714.

132. Varvel NH, Bhaskar K, Kounnas MZ, Wagner SL, Yang $\mathrm{Y}$, Lamb BT, et al. NSAIDs prevent, but do not reverse, neuronal cell cycle reentry in a mouse model of Alzheimer disease. J Clin Invest 2009;119:3692-3702.

133. Saijo K, Winner B, Carson CT, Collier JG, Boyer L, Rosenfeld MG, et al. A Nurrl/CoREST pathway in microglia and astrocytes protects dopaminergic neurons from inflammation-induced death. Cell 2009;137:47-59.

134. Simi A, Tsakiri N, Wang P, Rothwell NJ. Interleukin-1 and inflammatory neurodegeneration. Biochem Soc Trans 2007;35:1122-1126.

135. McCoy MK, Tansey MG. TNF signaling inhibition in the CNS: implications for normal brain function and neurodegenerative disease. J Neuroinflammation 2008;5: 45.

136. Alvarez V, Mata IF, González P, Lahoz CH, Martinez C, Peña $\mathrm{J}$, et al. Association between the TNFalpha-308 A/G polymorphism and the onset-age of Alzheimer disease. Am J Med Genet 2002;114:574-577.

137. Culpan D, MacGowan SH, Ford JM, Nicoll JA, Griffin WS, Dewar D, et al. Tumour necrosis factor-alpha gene polymorphisms and Alzheimer's disease. Neurosci Lett 2003;350:61-65.

138. Fung HC, Chen CM, Wu YR, Hsu WC, Ro LS, Lin JC, et al. Heat shock protein 70 and tumor necrosis factor alpha in Taiwanese patients with dementia. Dement Geriatr Cogn Disord 2005;20:1-7.

139. Nishimura M, Sakamoto T, Kaji R, Kawakami H. Influence of polymorphisms in the genes for cytokines and glutathione S-transferase omega on sporadic Alzheimer's disease. Neurosci Lett 2004;368:140-143.

140. Perry RT, Collins JS, Harrell LE, Acton RT, Go RC Investigation of association of 13 polymorphisms in eight genes in southeastern African American Alzheimer disease patients as compared to age-matched controls. Am J Med Genet 2001;105:332-342.

141. Tedde A, Putignano AL, Nacmias B, Bagnoli S, Cellini E, Sorbi S. Lack of association between TNF-alpha polymorphisms and Alzheimer's disease in an Italian cohort. Neurosci Lett 2008:446:139-142.

142. Green EK, Harris JM, Lemmon H, Lambert JC, Chartier-Harlin MC, St Clair D, et al. Are interleukin-1 gene polymorphisms risk factors or disease modifiers in AD? Neurology 2002;58:1566-1568.

143. Minster RL, DeKosky ST, Ganguli M, Belle S, Kamboh MI. Genetic association studies of interleukin-1 (IL-1A and $I L-1 B)$ and interleukin-1 receptor antagonist genes and the risk of Alzheimer's disease. Ann Neurol 2000;48:817-819.

144. Bosco P, Guéant-Rodríguez RM, Anello G, Romano A, Namour B, Spada RS, et al. Association of IL-1 $R N^{* 2}$ allele and methionine synthase 2756 AA genotype with dementia severity of sporadic Alzheimer's disease. J Neurol Neurosurg Psychiatry 2004;75:1036-1038.

145. Ehl C, Kölsch H, Ptok U, Jessen F, Schmitz S, Frahnert $\mathrm{C}$, et al. Association of an interleukin-1beta gene polymor- 
phism at position -511 with Alzheimer's disease. Int J Mol Med 2003;11:235-238.

146. Hedley R, Hallmayer J, Groth DM, Brooks WS, Gandy SE, Martins RN. Association of interleukin-1 polymorphisms with Alzheimer's disease in Australia. Ann Neurol 2002;51: 795-797.

147. Li XQ, Zhang JW, Zhang ZX, Chen D, Qu QM. Interleukin-1 gene cluster polymorphisms and risk of Alzheimer's disease in Chinese Han population. J Neural Transm 2004;111:1183-1190.

148. Mattila KM, Rinne JO, Lehtimäki T, Röyttä M, Ahonen $\mathrm{JP}$, Hurme M. Association of an interleukin $1 B$ gene polymorphism (-511) with Parkinson's disease in Finnish patients. J Med Genet 2002;39:400-402.

149. McCulley MC, Day IN, Holmes C. Association between interleukin 1-beta promoter (-511) polymorphism and depressive symptoms in Alzheimer's disease. Am J Med Genet B Neuropsychiatr Genet 2004;124B:50-53.

150. Nicoll JA, Mrak RE, Graham DI, Stewart J, Wilcock G, MacGowan S, et al. Association of interleukin-1 gene polymorphisms with Alzheimer's disease. Ann Neurol 2000;47:365-368.

151. Rosenmann H, Meiner Z, Dresner-Pollak R, Kahana E, Aladjem Z, Grenader $\mathrm{T}$, et al. Lack of association of interleukin-1beta polymorphism with Alzheimer's disease in the Jewish population. Neurosci Lett 2004;363:131-133.

152. Sciacca FL, Ferri C, Licastro F, Veglia F, Biunno I, Gavazzi A, et al. Interleukin-1B polymorphism is associated with age at onset of Alzheimer's disease. Neurobiol Aging 2003;24:927-931.

153. Seripa D, Matera MG, Dal Forno GD, Gravina C, Masullo $\mathrm{C}$, Daniele A, et al. Genotypes and haplotypes in the IL-1 gene cluster: analysis of two genetically and diagnostically distinct groups of Alzheimer patients. Neurobiol Aging 2005;26:455-464.

154. Wang HK, Hsu WC, Fung HC, Lin JC, Hsu HP, Wu YR, et al. Interleukin-1alpha and -1beta promoter polymorphisms in Taiwanese patients with dementia. Dement Geriatr Cogn Disord 2007;24:104-110.

155. Wang WF, Liao YC, Wu SL, Tsai FJ, Lee CC, Hua CS. Association of interleukin-1 beta and receptor antagonist gene polymorphisms with late onset Alzheimer's disease in Taiwan Chinese. Eur J Neurol 2005;12:609-613.

156. Wehr H, Bednarska-Makaruk M, Lojkowska W, Graban A, Hoffman-Zacharska D, Kuczyńska-Zardzewiały A, et al. Differences in risk factors for dementia with neurodegenerative traits and for vascular dementia. Dement Geriatr Cogn Disord 2006;22:1-7.

157. Yucesoy B, Peila R, White LR, Wu KM, Johnson VJ, Kashon ML, et al. Association of interleukin-1 gene polymorphisms with dementia in a community-based sample: the Honolulu-Asia Aging Study. Neurobiol Aging 2006;27: 211-217.

158. Ma SL, Tang NL, Lam LC, Chiu HF. Lack of association of the interleukin-1beta gene polymorphism with Alzheimer's disease in a Chinese Population. Dement Geriatr Cogn Disord 2003;16:265-268.

159. Di Bona D, Plaia A, Vasto S, Cavallone L, Lescai F, Franceschi $\mathrm{C}$, et al. Association between the interleukinlbeta polymorphisms and Alzheimer's disease: a systematic review and meta-analysis. Brain Res Rev 2008;59:155-163.

160. Wang $\mathrm{M}$, Song $\mathrm{H}$, Jia J. Interleukin-6 receptor gene polymorphisms were associated with sporadic Alzheimer's disease in Chinese Han. Brain Res 2010;1327:1-5.

161. Capurso C, Solfrizzi V, D'Introno A, Colacicco AM,
Capurso SA, Capurso A, et al. Interleukin 6-174 G/C promoter gene polymorphism and sporadic Alzheimer's disease: geographic allele and genotype variations in Europe. Exp Gerontol 2004;39:1567-1573.

162. Ravaglia G, Paola F, Maioli F, Martelli M, Montesi F, Bastagli L, et al. Interleukin-1beta and interleukin-6 gene polymorphisms as risk factors for AD: a prospective study. Exp Gerontol 2006;41:85-92.

163. Koivisto AM, Helisalmi S, Pihlajamäki J, Moilanen L, Kuusisto $\mathrm{J}$, Laakso $\mathrm{M}$, et al. Interleukin-6 promoter polymorphism and late-onset Alzheimer's disease in the Finnish population. J Neurogenet 2005;19:155-161.

164. van Oijen M, Arp PP, de Jong FJ, Hofman A, Koudstaal PJ, Uitterlinden AG, et al. Polymorphisms in the interleukin 6 and transforming growth factor betal gene and risk of dementia. The Rotterdam Study. Neurosci Lett 2006;402: 113-117.

165. Paradowski B, Celczynska D, Dobosz T, Noga L. Polymorphism $174 \mathrm{G} / \mathrm{C}$ of interleukin 6 gene in Alzheimer's disease-preliminary report. Neurol Neurochir Pol 2008; 42:312-315.

166. Capurso C, Solfrizzi V, Colacicco AM, D'Introno A, Frisardi V, Imbimbo BP, et al. Interleukin 6-174 G/C promoter and variable number of tandem repeats (VNTR) gene polymorphisms in sporadic Alzheimer's disease. Prog Neuropsychopharmacol Biol Psychiatry 2010;34:177-182.

167. He MX, Yang WL, Zhang MM, Lian YJ, Hua HY, Zeng $\mathrm{JS}$, et al. Association between interleukin-6 gene promoter $-572 C / G$ polymorphism and the risk of sporadic Alzheimer's disease. Neurol Sci 2010;31:165-168.

168. Infante J, Sanz C, Fernandez-Luna JL, Llorca J, Berciano $\mathrm{J}$, Combarros O. Gene-gene interaction between interleukin-6 and interleukin-10 reduces AD risk. Neurology 2004; 63:1135-1136.

169. Combarros O, van Duijn CM, Hammond N, Belbin O, Arias-Vásquez A, Cortina-Borja M, et al. Replication by the Epistasis Project of the interaction between the genes for IL-6 and IL-10 in the risk of Alzheimer's disease. $J$ Neuroinflammation 2009;6:22.

170. Vural P, Değirmencioğlu S, Parildar-Karpuzoğlu H, Doğru-Abbasoğlu S, Hanagasi HA, Karadağ $\mathrm{B}$, et al. The combinations of TNFalpha-308 and IL-6 -174 or IL-10 -1082 genes polymorphisms suggest an association with susceptibility to sporadic late-onset Alzheimer's disease. Acta Neurol Scand 2009;120:396-401.

171. Arosio B, Trabattoni D, Galimberti L, Bucciarelli P, Fasano $\mathrm{F}$, Calabresi $\mathrm{C}$, et al. Interleukin-10 and interleukin-6 gene polymorphisms as risk factors for Alzheimer's disease. Neurobiol Aging 2004;25:1009-1015.

172. Bagnoli S, Cellini E, Tedde A, Nacmias B, Piacentini S, Bessi V, et al. Association of IL10 promoter polymorphism in Italian Alzheimer's disease. Neurosci Lett 2007;418: 262-265.

173. Lio D, Licastro F, Scola L, Chiappelli M, Grimaldi LM, Crivello A, et al. Interleukin-10 promoter polymorphism in sporadic Alzheimer's disease. Genes Immun 2003;4:234238.

174. Scassellati C, Zanardini R, Squitti R, Bocchio-Chiavetto L, Bonvicini C, Binetti $\mathrm{G}$, et al. Promoter haplotypes of interleukin-10 gene and sporadic Alzheimer's disease. Neurosci Lett 2004;356:119-122.

175. Ma SL, Tang NL, Lam LC, Chiu HF. The association between promoter polymorphism of the interleukin-10 gene and Alzheimer's disease. Neurobiol Aging 2005;26:10051010. 
176. Giedraitis V, Kilander L, Degerman-Gunnarsson M, Sundelöf J, Axelsson T, Syvänen AC, et al. Genetic analysis of Alzheimer's disease in the Uppsala Longitudinal Study of Adult Men. Dement Geriatr Cogn Disord 2009; 27:59-68.

177. Depboylu C, Du Y, Muüller U, Kurz A, Zimmer R, Riemenschneider $\mathrm{M}$, et al. Lack of association of interleukin-10 promoter region polymorphisms with Alzheimer's disease. Neurosci Lett 2003;342:132-134.

178. Cousin E, Macé S, Rocher C, Dib C, Muzard G, Hannequin $\mathrm{D}$, et al. No replication of genetic association between candidate polymorphisms and Alzheimer's disease. Neurobiol Aging 2011;32:1443-1451.

179. Candore G, Balistreri CR, Grimaldi MP, Listi F, Vasto S, Chiappelli M, et al. Polymorphisms of pro-inflammatory genes and Alzheimer's disease risk: a pharmacogenomic approach. Mech Ageing Dev 2007;128:67-75.

180. Arosio B, Mastronardi L, Vergani C, Annoni G. Intereleukin-10 promoter polymorphism in mild cognitive impairment and in its clinical evolution. Int $J$ Alzheimers Dis 2010;2010.

181. Ma SL, Tang NL, Zhang YP, Ji LD, Tam CW, Lui VW, et al. Association of prostaglandin-endoperoxide synthase 2 (PTGS2) polymorphisms and Alzheimer's disease in Chinese. Neurobiol Aging 2008;29:856-860.

182. Listi F, Caruso C, Lio D, Colonna-Romano G, Chiappelli $\mathrm{M}$, Licastro $\mathrm{F}$, et al. Role of cyclooxygenase-2 and 5-lipoxygenase polymorphisms in Alzheimer's disease in a population from northern Italy: implication for pharmacogenomics. J Alzheimers Dis 2010;19:551-557.

183. Abdullah L, Ait-Ghezala G, Crawford F, Crowell TA, Barker WW, Duara R, et al. The cyclooxygenase 2-765 C promoter allele is a protective factor for Alzheimer's disease. Neurosci Lett 2006;395:240-243.

184. Choi JK, Jenkins BG, Carreras I, Kaymakcalan S, Cormier $\mathrm{K}$, Kowall NW, et al. Anti-inflammatory treatment in $A D$ mice protects against neuronal pathology. Exp Neurol 2010;223:377-384.

185. Nivsarkar M, Banerjee A, Padh H. Cyclooxygenase inhibitors: a novel direction for Alzheimer's management.
Pharmacol Rep 2008;60:692-698.

186. Ioannidis JP, Trikalinos TA, Khoury MJ. Implications of small effect sizes of individual genetic variants on the design and interpretation of genetic association studies of complex diseases. Am J Epidemiol 2006;164:609-614.

187. Evans DM, Visscher PM, Wray NR. Harnessing the information contained within genome-wide association studies to improve individual prediction of complex disease risk. Hum Mol Genet 2009;18:3525-3531.

188. Lango H; UK Type 2 Diabetes Genetics Consortium, Palmer CN, Morris AD, Zeggini E, Hattersley AT, McCarthy MI, et al. Assessing the combined impact of 18 common genetic variants of modest effect sizes on type 2 diabetes risk. Diabetes 2008;57:3129-3135.

189. Khoury MJ, Yang Q, Gwinn M, Little J, Dana Flanders W. An epidemiologic assessment of genomic profiling for measuring susceptibility to common diseases and targeting interventions. Genet Med 2004;6:38-47.

190. Grupe A, Abraham R, Li Y, Rowland C, Hollingworth P, Morgan A, et al. Evidence for novel susceptibility genes for late-onset Alzheimer's disease from a genome-wide association study of putative functional variants. Hum Mol Genet 2007; 16:865-873.

191. Abraham R, Moskvina V, Sims R, Hollingworth P, Morgan A, Georgieva L, et al. A genome-wide association study for late-onset Alzheimer's disease using DNA pooling. BMC Med Genomics 2008;1:44.

192. Bertram L, Lange C, Mullin K, Parkinson M, Hsiao M, Hogan MF, et al. Genome-wide association analysis reveals putative Alzheimer's disease susceptibility loci in addition to APOE. Am J Hum Genet 2008;83:623-632.

193. Beecham GW, Martin ER, Li YJ, Slifer MA, Gilbert JR, Haines JL, et al. Genome-wide association study implicates a chromosome 12 risk locus for late-onset Alzheimer disease. Am J Hum Genet 2009;84:35-43.

194. Feulner TM, Laws SM, Friedrich P, Wagenpfeil S, Wurst $\mathrm{SH}$, Riehle $\mathrm{C}$, et al. Examination of the current top candidate genes for $A D$ in a genome-wide association study. Mol Psychiatry 2010;15:756-766. 